\title{
PHILIP LARKIN AND SHAMSUR RAHMAN: A COMPARATIVE STUDY
}

\section{Sultana Jahan}

Assistant Professor Department of English Language and Literature International Islamic University Chittagong

http://dx.doi.org/10.26739/2573-5616-2018-1-2-1

Abstract: Bengali poet Shamsur Rahman is considered the most significant successor of the first generation of the modernists who successfully shake off Rabindranath's romantic notion and incorporated Western Modernism. Likewise, Philip Larkin belonged to the Modernist period that is also characterised by the rejection of 19th-century poetic tradition. Both Shamsur Rahman and Philip Larkin are similar in their debut as they capture the spirit of Modernist experiment marked by the distinct formal rhythm, colloquial language, and dark, doubtful and degenerative tone and conversational style. Both poets in their poems reflected dark and drab reality of the post-war world. With sad-eyed realism, they explored the dark area of the human mind with the confessional mode. They even take up the same themes like death, alienation, pessimism, boredom and love and sexuality. This paper attempts to make a parallel structure between two poets belonging to two nations.

Keywords: New Poems, Urbanization, Confessional Note 
To the poets of Kollol-era, the first 'modern' phase of Bangla poetry, the post-war world appears as a vast expanse of an arid landscape that has generated scepticism, rootlessness and nihilism. These senses of divergence and fragmentation create in their minds an urge for rebellion against the established norms of the society that have constituted anti-Tagore stance.

The poets of the 1930s brought to twentieth-century poetry a new voice, and they brought a sharp awareness of the contemporary time. The trend, which influenced the whole literary world of Europe immediately after the end of World War 11, had also affected Bengali Literature and freed it from the tendency of Rabindranath Tagore. Poet of 30s follows Baudelaire, Mallarme, Valery and other French Symbolists and disillusioned idealists, who sought in poetry an escape from the ugliness, hypocrisy, and alienation and disorder of modern mind, and resolved the contradictory conditions of dream and reality into an absolute fact, a super-reality. Later they were influenced by the Imagist movement of Ezra Pound and Eliot's idea of poet's extinction of personality and sense of tradition. Andre Breton's surrealistic movement also has significant impact on some of the poets of Kollol-era.

This trend influenced by the post-war reconstruction which the poet of the 30s brought in the European literature, comprises the following features:

1. Post-war condition of the world is reflected in the poems

2. Striving for the new style

3. Sway of increased urbanisation

4. Pessimism and exhaustion

5. The influence of Freud and literature is dominant with the inconsistency of sub-conscious mind.

6. Disbelief in God and traditional ethics

7. Sense of rootlessness

8. Identity crisis

9. Loss of identity

In the 1930s a new literary Movement started by John Wain, Donald Davie, Kingsley Amiss, Thom Gunn and a couple of others rose. Phillip Larkin was personally identified with the Movement. These writers were accepted to have defied the inflated romanticism of the nineteen-thirties and nineteen-forties. The Movement was the result of some particular perspectives about writing and Social science and humanities

Generalization of scientific results 
society. This gathering shared another arrangement of thoughts and presumptions firmly identified with the dispositions and states of post-war England. A considerable lot of Larkin's lyrics roughly mirror some of those qualities and suspicions.

In the domain of Bengali literature, some outstanding poets of the 30s like Buddhadev Bashu, Jibanananda Das, Shudhindranath Datta, Bishnu Dey and Amiya Cakravorti were much inspired by this wave of English Literature after World War II. Not only that the world literature inspired the poets of the 30s, but they also acted as the only source of spirit and brainwave of the next generation. The contemporary Bengali literature is somewhat an extension of the practice and aesthetics of the 1930s. During the post-Rabindranath era, the poets of the 30s commenced a new kind of sensibility and emotion among the readers giving Bengali language a ground-breaking shape in their poems. Though in most cases they contributed to Bangla Literature on their own, this group did have a shared set of values. Shamsur Rahman is one of the most significant successors of this value and creative expressions.

During the last quarter of the 1940s and at the beginning of the 1950s Shamsur Rahman appeared as a poet in the realm of Bengali literature. In spite of confining himself to the tradition of following Nazrul and Jibananda Das in his initial phase, he eventually exposed his poetic self to a new horizon. He broke the rules of metrical poems as well as freed himself from the influence of Rabindranath. He consciously accepted the experimentation of poets of the 30 s as his ideal. He blew a flash of wind from the ocean into a stagnant pool by introducing simplicity, spontaneity, and conversational style in his poems. He broke the tradition of ornamented poetic structure and rediscovered elements of poems from everyday life and its intelligible and lucid language.

Likewise, Phillip Larkin showed up as an artist in 50s and joined the Movement involving John Wain, Donald Davie, Kingsley Amiss, Thom Gunn who put stock in like manner sense and lucidity over lack of definition and perplexity. Elaborately, the artists of this Movement shared a shirking of rhetoric, and they employed a harsh tone and colloquial idiom. Though Shamsur Rahman and Philip Larkin are different in their language, culture and nationality, there are surprising similarities between the two poets belonging to two distant shores.

Both the poets share a remarkable similarity in the starting point of their career. Shamsur Rahman started his career including his poems in an anthology of poems entitled Notun Kabita (New poems) and likewise, Larkin, at his starting Social science and humanities

Generalization of scientific results 
point, along with other poets of the Movement published a collection of poems entitled Newlines. More importantly, both the anthologies of poems represented a new and healthy general standpoint and the restoration of a sound and pleasant attitude to poetry.

Stylistically, their poems are quite identical in the clarity of expression, prose rhythm, and colloquial ease. Both the poets have a kind of confessional notes in their poems; they are also similar in their narrative style: both of them use story-telling technique in their poems. Thematically, as both of them are war poets, they are identical in exposing agnosticism, insignificance, emptiness and vainness of existence. Besides, both poets are similar in exploring the themes of acute loneliness, an inevitability of death, loss of identity with a cynical observation of life.

Larkin attempted to use colloquial words and phrases, and the use of plain diction, to reproduce in his poems the real language of the people. Clarity was one of the aims of his poetry. More importantly, the colloquial manner is one of the most striking features of Larkin's poetic technique. For example, the poem 'Toads' begins conversationally:

Why should I let the toad work?

Squat on my life (54)

With the colloquial style, he frequently utilized a touch of discourse in the lyric. The proprietor reveals to Larkin that Bleaney used to take care of her garden, while Larkin tells the landlord that he would consume his space. There are likely some troublesome words and expressions in this ballad which are exceptionally a long way from the plain style prescribed by the Movement, yet the informal way and the relatively conversational style of the lyric compensate for the insufficiency. Larkin employs several kinds of stanza in his poetry; the quatrain is the form of the stanza which he frequently employs; his metrics are thus traditional. His repetitive use of the conversational, colloquial manner includes swearing words and coarse, even vulgar language.

Shamsur Rahman composed the greater part of his sonnets in free verse, frequently with the mood style known as Poyaar or Okhshorbritto. It is prevalently realized that he took after this example from writer Jibanananda Das. He likewise composed sonnets in two other real examples of Bengali musical style, in particular, Matrabritto and Shwarobritto (Islam, n.p.). For example, "You are a garden room, the koel-bird's song/ the old banyan tree's gleaming leaves/ my notebook of poems written just as I please." Similarly, use of colloquial words, Social science and humanities

Generalization of scientific results 
vulgarity and conversational style are common in Shamsur Rahman's poetry (Islam, n.p.). Though he engaged himself with the breaking of the metrical poem, he would feel comfortable to write an Okhshorbritto rhyme. Even in his unmetrical poems, the rhythm of Okhshorbiritto is evident. He also used a variety of rhymes like matrabritto, okkhorbritto, shorobritto, amritakkhor and so on. Because of his use of plain language and conversational style, at times it is difficult, rather confusing to determine whether it is Okkhorbritto or un-metrical in nature:

জানি না কী করে কার মমতার মতো

শান্ত সুভ্র ভোর এঙে ঝরে।

জানি না কী করে এত নীল হয় বোজ

ধ্রুপদী আকাশ, ঘাঙে এত রঙ, বোদে

জীবনের সাড়া, বিকেল হাওয়ায় এত নির্জন ভাষা

(জানল না কেউ) তবু কী করে যে বেঁচে আছে তারা।

(Rahman, “Mane-Mane” 207)

A striking similarity between these two poets is reflected in their confessional notes. The confessional notes, disclosing their unspoken and secret autobiographical elements in their poetry make them frantic, sometimes lunatic or self-destructive. Sometimes their poems reflect the distortion of mind. Instead of colouring the autobiographical component with imagination, they pick up their life in poetry barely and nakedly. Their poems are full of secret anguish, psychological disease, sexual crime, addiction and so on. In such confessional poems the ' $\mathrm{I}$ ' pronoun indicates the poet himself. The whole autobiography is used conspicuously.

However, Shamsur Rahman is, to some extent, different as he never opens the secret door of his life entirely. Though he frequently uses ' $\mathrm{I}$ ' and indicates himself, in most cases his ' $\mathrm{I}$ ' seems to be objective and artistic. However, confessional notes are evident in many of his poems containing the themes of war, love or sexuality. He reflects the contemporary socio-political turmoil and portrays malice and vicious time in his poems; sometimes he feels frantic, sometimes he feels pain at a depth of heart. For example, his frenzied and Social science and humanities

Generalization of scientific results 
hysterical attitude results from the enormous havoc caused by natural calamity to the people of the sea-shore: Through confessional notes, he discloses his phobia as he is terrified seeing innumerable melting dead bodies.

In many of his poems, confessional notes are evident. He has given confessional description of sexual intercourse in many of his poems. Shamsur Rahman wrote many confessional poems involving his self with every affair of contemporary society inseparably: to utter ' $I$ ' repetitively is intrinsic in him and consequently, a considerable portion of autobiographical elements are evident in his poems. Probably, he is unparallel in exposing himself in his poetry - his personal life, his relationship with others, above all, everything about his self. His abundant use of autobiographical elements and its resourcefulness, in many cases, make him confessional. We can quote a poem by Rahman that contains confessional elements:

We were five pals, sharing the same cup -

One has got killed in the War, one is a tramp

Scouring the streets with dirt under his nails,

And almost naked, picks trash and holds conversations

With insects day and night, pats the cheeks of darkness.

Another young man who had a deep groove

On his sharp chin has killed himself.

(Rahman, "Idanim Suitcase", qtd in Hossain 133)

Philip Larkin once said of himself in one of his rare newspaper interviews, "I think it's very sensible not to let people know what you're like'. There are very few occasions when Larkin assumes a persona, and in the ' $\mathrm{I}$ ' poems he is speaking to us directly in his own voice. When Larkin wants to explore the same area more seriously, he has only to slip into another, less obvious persona, more closely related to his own character. In 'Dockery and Son' (the Whitsun Weddings) the ' $\mathrm{I}$ ' figure visits what sounds very much like an Oxford college (Larkin was at St John's, Oxford) and chats with the Dean. In his several poems, Larkin lets himself be directly involved with his fellow-men without the distancing shield of a persona. Sometimes 'we' has taken over 'I', or, rather, 'I' has become blended with 'we'.

Startlingly, both the poets dealt with the din and bustle of city life and wrote for the middle-class society. Shamsur Rahman is called the poet of Dhaka city. Their observation about increased urbanisation is manifest in many of their Social science and humanities

Generalization of scientific results 
poems. Most of their poems are enriched with imagery taken from the hustle and bustle of amplified urbanisation and the daily life of the city people. Urbane life, especially the life of Dhaka, occupies a prominent place of his poetry. In one of the interviews, Shamsur Rahman himself asserts: 'I was born in Dhaka; city life comes to my poetry spontaneously. My relationship with the town is deep. My heart and soul becomes urbane.' Famous novelist Akhtaruzzaman Ilias comments,

'He is the citizen of Dhaka; he is nourished with light and air of this city; he views Dhaka sometimes like an alien, sometimes as a beloved. Nothing becomes monotonous in this city; he exposes its glamour sometimes through the curiosity of an expatriate, sometimes through the eyes of a worried lover. He missed nothing of this city: -- damp slums, lamp post, foot path, park, a push cart, procession, and public-gathering -- above all, the depiction of the city in the burning Johto or sodden and rainy Shrabana. (qtd in Sumon 64)

He becomes the running commentator of the city life. His city life is fatigued and worn out like Baudelaire's dark world, world of sick, beggar, gamblers and whores. His love for this city is present in many of his poems abstractly or concretely. The worth-mentioning poems about this city are 'E Shohor Dhakatei', 'Jostnai bhashchhe Dhaka', 'Hei Shohor, Hei Antorongo Amar' etc.

In many of Phillip Larkin's poems like 'Church Going', 'Afternoons', 'The Whitsun Weddings' and so on, the impact of urbanisation in England is given a meticulous expression. He cynically responds to the whole modernising, and commercialising of post-war England. A critic comments that in spite of the fact that Larkin is frequently observed as a writer who observes England and Englishness, he keeps up a conscious separation from the farmland and from the general population who occupy the wide open. A significant number of Larkin's sonnets, says this pundit, delineate England as relentlessly vanishing and along these lines needing being seen plainly in the present.

Both poets' pessimism and disappointment in life result from the drab and austere experience of the Second World War. The poetic self of Shamsur Rahman is shaped, to a great extent, by the Second World War and more particularly by the process of independence of the Subcontinent from the British rule. In one of his poems "Prothom Gan Ditio Mrittur Agae" ("First Song before the Second Death") the poet's detestable and loathsome memory of the war is reflected. This is not a conflict between reality and imagination. This conflict is much complicated as his imagination is full of hellish sight and experienced with a Social science and humanities

Generalization of scientific results 
poisonous bite of death. The poet is alienated as dejection and depression are destroying his imaginative dreamland. In his 'Roudra Korotite' the poet returns from dejected dreamland and enters a shiny, fierce and pungent earthy hell full of fatigue, where is no dream, beauty and peace; there prevails only faded beauty, destructive loneliness and emptiness of existence.

Similarly, in several of Larkin's poems like "Nothing to be said", "Going", "The Building", "The old fools", 'Ambulance', 'Next, please', 'A Young Lady's Album', profound pessimism is evident. In many of his poems, the outlook is so gloomy that man seems to be a helpless victim of circumstances. Man is depicted in his poems as a victim of social conditions; the majority of his poems reflect his disappointment and dismay at the spectacle of the life around him. In the poem 'Going' Larkin speaks of death as an evening which is coming across the fields, an evening never seen before, an evening which brings no comfort at all. The poet depicts himself in this poem as an absolutely insignificant item in the scheme of things. Even the poem entitled 'The Whitsun Weddings', in which there is no deep gloom and in which the poet shows himself to be a detached observer, has a pessimistic side to it. Even the poems like Mr. Bleaney, Toads, and Toads Revisited, which are not very pessimistic, contain a streak of sadness and despondency. And there is the poem 'Dockery and son' which ends with the depressing lines about life being first boredom, then fear, and then to the end of old age. And even more pessimistic is the poem called 'Aubade'

Both the poets are also identical in expressing their agnosticism and scepticism. In the poem "Church Going", Larkin foresees the utter loss of faith and a consequent decline in the importance of church. In this poem he communicates his rationalist dispute and shows a picture of the post-war, welfare state Englishman in the lines "Hatless, I Take Off/My Cycle-Clips In Awkward Reverence". It is the picture of a ratty Englishman who isn't worried about his appearance yet who is poor, having a bicycle not an auto; that is awkward but rather loaded with skeptic devotion; that is deprived, come up short on, finished exhausted, trust less and exhausted. The speaker in this lyric shows up as freethinker, and the entire contention in the lyric is that the houses of worship would keep on providing some enthusiastic and otherworldly comfort to a few people even after the present confidence in God and future life has crumpled and offered away to wariness. Hence while Larkin expels the idea of a congregation is a place of God, he yet trusts that houses of worship would keep on serving 
some enthusiastic or profound reason even after individuals' dismissal of the present religious convictions. Here religion is reduced to superstition.

Similarly, Shamsur Rahman trivialises religion and faith in several of his poems. In most of his poems the splendid subjects like God, soul, well wish etc. being discharged from and magnanimity as he says 'Will I totter a soul wrapped in a piece of yellow lifeless paper?/ Really a tiny spiritual lump'.

Both Shamsur Rahman and Phillip Larkin are war poets. Both of them depict hollowness of the dark and drab reality. In Shamsur Rahman's Biddhasta Nileema attacked by the murderous time, his dream, civilization, and many things are on the point of destruction. The poet enters an unfavourable world and portrays a devastating and ruined civilization. In some poems, he described the fatal time, riot, First World War, heart-rending independence, unlimited waste of lives above all meaningless and tattered reality. He made us understand how the peaceful domestic life is destroyed by the havoc of war. He first mentioned the picture of domestic happiness like the nest, the warmth of kiss, colourful butterfly like a childhood memory, then he took the reference of the World War II devastated Hiroshima, the explosion of the atom bomb, refugee, pile of dead bodies, immoral sexuality of the fighters and what not.

Similarly, Larkin's pessimism, to a great extent, is caused by the devastating brutality of unexpected First World War. He has regularly been known as the hesitant artist of the dull and somber surfaces of post-war Britain. He wrote several poems depicting the brutal picture and the upshot of war. His famous war poem is 'MCMXIV'. The Roman numerals are perhaps deliberately used to record not only the year but the legions queuing up to fight. The poem superbly controlled and perhaps referred to old photographs to convey the full atmosphere of the time which evokes the past in August 1914 at the beginning of the First World War. MCMXIV changed everything. It became the terrible experience that followed natural innocence. Marriages were broken by deaths and values were changed in the years to come, and the old ways became the past.

Both the poets wrote many poems about death. One of the major themes of their poems is the fear of inevitable death. Their outlook on life is undoubtedly bleak and gloomy, and their disappointment and dismay are deepened by their constant references to the inevitability of death. Larkin's 'Ambulance' adds a new dimension to the theme of death. Larkin fears death; he quails at the thought of death. Only in one poem, namely 'The Explosion', he exalts death as a means of 
bringing honour to the persons who were killed in an explosion. In general, he harbours a dread of death.

Likewise, Shamsur Rahman wrote many poems regarding death. The theme of death is obvious in many of his poems like 'Ekjon Kobi: Tar Mrittu', Eshechhi Dafon Kore,' 'Asader Shirt', 'Amar Mrittur pore' and others. In these poems, he wrote about both individual and collective approach to death. Surprisingly, the theme of death is given manifestation in his first poem. Using the myth of Lazarus, he states the experience of death after coming back to his ever-enchanting earth. Experience of death gives him a ground-breaking view of disconnection and separation. Like a spirit, he is roaming around the human habitation as if he were a forlorn and wandering ascetic. He expresses like Prufrock-----'I am Lazarus, come from the dead, / come back to tell you all'.

One of the major features of a modern poet is the sense of detachment. The emptiness of existence, depression, anguish caused by isolation are manifest in the poets of the 30s. Shamsur Rahman by inheritance was inspired by this sense of alienation. The alien characters of his poems sometimes become lonely passerby, destitute refugee, or sometimes mere a mouthful of dust. They do not know their destination; they only question about their absurd existence. The absurdity and trivialities of existence are given exquisite expression in many of his poems. Likewise, in many of Larkin's poems, sense of alienation is evident. In his 'To the sea', 'At grass', 'Going Going' and other poems he creates an empty, bare, soundless and lonely world. He is attracted to a wasteland that is strewn with scrub and debris. 'In a time of global concept', Larkin wrote, Betjeman insisted on 'the little, the forgotten, the unprofitable, the obscure.'

A modern poet surrounded by everybody is always an alien and different from others. Their sense of alienation is given an exquisite expression in their use of imagery: mostly, the imagery used by them pertains to the ordinary, everyday sights and occurrences. Larkin, in his 'Church Going' the image of the interior of the church has vividly and realistically portrayed, while in the other poem, the sight seen by Larkin on the successive railway stations and the sights witnessed by him through the window of the railway train as it speeds onwards have also the same stamp of authenticity; and all these sights are of the everyday, familiar kind with nothing exceptional about it. Similarly, Samsur Rahman expresses his sense of loneliness, pessimism or his disgust about war using very familiar kind of imagery.... In using imagery both poets have bought an unprecedented change and their pessimism, skepticism, sense of trivialities of lives have been Social science and humanities

Generalization of scientific results 
articulated in the innovative use of image. They have bought different taste and manifestation of language.

Another worth-mentioning similarity between these two poets is that both of them dealt with ordinary kind of people and the everyday reality of the middle-class community. Larkin creates much poetry out of common and unexceptional people, scenes, happenings, and occurrences. The protagonists in some of Larkin's best-known poems are also persons of ordinary kind. Mr. Bleaney in the poetry of that name is a most usual fellow who worked in a motor car and who lived in a shabby room rented by him. Shamsur Rahman is also called the poet of the middle class. Dhaka city and its inhabitants-- slum-dwellers, prostitute, street-children, labour, beggar, drunken, language martyr, freedom fighter, everybody is vigorously manifest in his poems. He hardly existed in a dream; instead, he picked and chose the contemporary society and its exploitation, deprivation, famine, hope, love, lust, freedom and confinement, politics and other innumerable tribulations for his poems.

Apart from some aspects of similarities, there are some specific dissimilarities between them. Firstly, their attitude to love and sex is not the same. Secondly, whereas Larkin was against the intellectualisation of poetry and to simplify his language he hardly used mythology or other references, Shamsur Rahman used mythological references extensively.

Love and sexual act in Larkin's ballad seem misleading, and its guarantee turns out to be vacant or false. Larkin's affection sonnets are regularly frustrated reflections on disappointment, weakness, and defenselessness. The lyric 'relational unions' critically reports that much of the time marriage involves tolerating a bothersome accomplice in whose organization such words as freedom, drive, and excellence can never be specified. In Larkin's verse, love guarantees 'to fathom and fulfill' however it additionally debilitates the freedom of the person. In the sonnet 'Dry Point' physical experience is displayed as a battle joined by dread and frenzy. In the sonnet 'Lines on a Young Ladies Photograph Album', we run over a progression of sensual dreams about the lady's body, particularly when it is 'yielded up' and when it is once open. A large number of Larkin's sonnet offers a specific proclamation of sexuality in which a developing liberal mentality is adjusted against customary thoughts of sexual romance and lead. At the point when the volume entitled 'High Windows' was distributed, this angled sensuality in Larkin's verse had offered approach to real and even obscene vocabulary.

Social science and humanities

Generalization of scientific results 
However, a considerable portion of Shamsur Rahman's poetry is occupied with his love poems. Like the other poets of the 30s, Shamsur Rahman discards the idea of spiritual and abstract love. Love means to him physical excitement, eroticism or obscenity. His partner is not like Jibonanondo's Bonolota Sen who exists only in a dream. Like Jibonanondo, Shamsur Rahman is not contented just to sit by her in the dark evening; rather he needs to have her in bed as a sexual partner.

In the history of Bangle literature, the poet of 30s began the anti-Tagore, and modernist stance and the poets of the Fifties Quartet injected a substance into that poetry. Avoiding communal and religious perspective, Shamsur Rahman branched out into profane poetry. Obviously, they obtained from the west Baudelaire, Eliot and others. Shamsur Rahman's initial verse was in a general sense imagined in the shadow of Baudelaire. Sentiment offers approach to dread of the city.

The bursts of Second World War were all the while consuming in the late nineteen-fifties, and there was a decay in the esteem. That was also a scenario Philip Larkin wrote poetry with anti-romanticism and agnostic approach. Though he incorporated the modernist pessimism, scepticism and complexities, he reacted against T.S Eliot and Ezra Pound's imagist and symbolist movement. Similarly, Shamsur Rahman, though build up his career on the poetic ideology of the 30s, he successfully gives a new shape to Bengali poetry introducing colloquialism, conversational style, crude and gross expression and confessional mode. In spite of belonging to two different nations, they are similar to experimenting new styles and bringing fresh air in the domain of literature. 


\section{References}

Hossain, Khondakar Ashraf. Western Influences on Bangladeshi Poetry. Dhaka: University of Dhaka, 2010. Print.

Islam, Mir Md Ariful. "Shamsur Rahman, the lonely Sherpa of Bangla literature". Young Observer. The Daily Observer. 26 October, 2017. http://www.observerbd.com/details.php?id=102278.

Larkin, Philip. Philip Larkin: Collected Poems. London: Faber and Faber, 2003. Print.

Rahman, Shamsur. Shamsur Rahmaner Sresta Kabita. Dhaka: Sahitto Prokash, 2009. Print.

Summon, Faruk. Shasur Rahmaner Kabita, Nagar Chetana O Nagorik Onsonga. Dhaka: Rabeya Books, 2015. Print.

Syeed, Abdul Mannan. Ishwar Gupta Theke Shaheed Qadri. Dhaka: Suchipara, 2007. Print. 